\title{
Succession of crustose coralline red algae (Rhodophyta) on coralgal reefs exposed to physical disturbance in the southwest Atlantic
}

\author{
Rodrigo Mariath · Rafael Riosmena Rodriguez • \\ Marcia A. O. Figueiredo
}

Received: 4 November 2011/Revised: 25 February 2013/Accepted: 3 April 2013/Published online: 14 May 2013

(C) Springer-Verlag Berlin Heidelberg and AWI 2013

\begin{abstract}
Biological and physical disturbances create the conditions for species succession in any biological ecosystem. In particular, coral reefs are susceptible to this process because of the complexity of their ecological relationships. In the southwest Atlantic, nearshore reefs are mostly coated by a thin layer of coralline crusts rather than stony corals. However, little is known about the succession of crustose coralline algae. We studied this process by means of a series of experimental and control discs exposed to physical disturbance. Our results showed that the dominant species in natural conditions, Pneophyllum conicum, had early recruits and later became dominant on the discs, replicating the community structure of the actual reef. This species had mature reproductive structures and available spores from the beginning of the colonization experiments. Thicker crusts of Porolithon pachydermum and Peyssonnelia sp. were found on the discs after 112 days, and significantly increased their cover over the succeeding months; and after 1 year, $P$. conicum was less
\end{abstract}

Communicated by I. Bartsch.

\section{R. Mariath}

Programa de Pós-Graduação em Botânica, Escola Nacional de Botânica Tropical, Instituto de Pesquisas Jardim Botânico de Rio de Janeiro, Rua Pacheco Leão 2040,

Rio de Janeiro, RJ 22460-030, Brazil

\section{R. R. Rodriguez ( $\square)$}

Programa de Investigación en Botánica Marina,

Departamento de Biología Marina, Universidad Autónoma

de Baja California Sur, 23080 La Paz, B.C.S, Mexico

e-mail: riosmena@uabcs.mx

M. A. O. Figueiredo

Instituto de Pesquisas Jardim Botânico de Rio de Janeiro,

Rua Pacheco Leão 915, Rio de Janeiro, RJ 22460-030, Brazil abundant. Physical disturbance increased crust recruitment and the low-light environment created by sediments. The data demonstrated coexistence among crustose coralline species and a tolerance to physical disturbance, which seemed to favor the thinner crusts of $P$. conicum over thick-crust species during succession. The succession pattern observed in this subtropical Brazilian coral reef differs from that described for shallow tropical reef communities.

Keywords CCA · Coral reef - Benthic communities . Brazil

\section{Introduction}

Brazilian coral reefs differ from the classical example of the Great Barrier Reef, for example, mainly in the important role of crustose coralline algae (hereafter CCA) as a living cover (Table 1), in addition to their role in the construction of reef structure. The nearshore bank reefs are surrounded and even filled with muddy siliciclastic sediments. The coral fauna is not diverse but is rich in endemic species, and their offshore reefs may be shaped into unique mushroom columns (Leão and Dominguez 2000). On the windward side of the bank reefs is an abundant algal rim composed by CCA together with vermetid gastropods (Leão 1996). Recently, human impacts have affected the cover of reef-building corals in this region (Dutra et al. 2004), mostly through large increases in sediment deposition (Leão and Kikuchi 2005). The reef-building corals and CCA are relatively little studied (Leão 1996).

Species composition and cover of CCA and corals on the emergent banks of Brazilian reefs have been observed to change markedly at different intervals (Leão and Kikuchi 2005; Figueiredo et al. 2008). Turf algae, fleshy algae 
Table 1 Abundance of crustose coralline algae on diverse reef flats in the southwestern Atlantic

\begin{tabular}{lc}
\hline Place & Relative abundance \\
\hline Abrolhos reefs & $32-79 \%$ in Figueiredo (1997); 4-36\% in Villaça and Pitombo (1997); 2-15\% \\
& in Figueiredo and Steneck (2002); 3-40\% in Figueiredo (2006); 10-20\% \\
& in Tâmega and Figueiredo (2007) \\
Rocas Atoll & $36-60 \%$ in Gherardi and Bosence (2001); 30-50\% in Villas Boas et al. (2005) \\
Coroa Vermelha and Ponta Grande & $30-40 \%$ in Costa et al. (2002) \\
Recife de Fora (studied site) & $30-49 \%$ in present work
\end{tabular}

and CCA are the most abundant algal elements on the coastal reefs. CCA may reach their maximum development on the seaward offshore reef (Costa et al. 2002), where they are probably exposed to higher grazing pressure (Steneck 1988; Steneck and Dethier 1994).

Ecological experiments have shown that CCA may be one of the first colonizers of hard substrates (Quinn 1982; Steneck 1986). The success of this colonization depends on the growth strategy of each species in the competition for space (Paine 1984; Steneck et al. 1991; Keats and Maneveldt 1994; Keats et al. 1994) in relation to physical conditions (Littler and Littler 1984; Kendrick 1991; Steneck and Dethier 1994) or biological disturbances (Paine 1984; Steneck et al. 1991). Figueiredo (1997) showed that CCA in the southwest Atlantic have a similar degree of cover on wave-exposed offshore reefs after 3-5 months of colonization, in shallow zones dominated by Porolithon pachydermum (Foslie) Foslie and Lithophyllum congestum (Foslie) Foslie (Figueiredo and Steneck 2002; Figueiredo 2006; Figueiredo et al. 2008).

Coralline crusts with a thin thallus such as Mesophyllum spp. are primarily found under macroalgal canopies and low-light environments, contrasting with the massive or complexly branched species such as Porolithon pachydermum and Lithophyllum congestum in sunlit shallow zones with little fleshy algae (Figueiredo and Steneck 2002). Thick crusts are generally considered to be competitively superior to thinner crusts (Steneck 1986; Dethier et al. 1991), but the reverse might be expected in highly grazed environments (Steneck et al. 1991). As the taxonomy of this algal group is complex, there are limited studies on their ecological relationships (Ringeltaube and Harvey 2005), especially on sediment disturbance, which may influence their succession sequence on reefs.

Porolithon pachydermum and Lithophyllum congestum dominate the higher levels of Caribbean algal ridges, with a smaller standing crop of fleshy algae (Adey and Vassar 1975; Adey 1998). The only study of succession among CCA demonstrated their adaptation to lower-light levels (Adey and Vassar 1975). This study showed that Neogoniolithon megacarpum gradually replaces other crustose species when a reduction in wave action or grazing allows a massive development of fleshy algae. However, no experimental evaluation of succession has been done to determine whether their succession sequence eventually produces a community that resembles the natural coralline abundance on reef in a sediment-disturbed environment.

The main aim of the present study was to evaluate the species abundance of CCA in several succession stages, in relation to a continuous physical disturbance. We hypothesized that CCA species will interact at the beginning of succession, and later only one species with a thick thallus will become dominant, provided that macroalgae and trapped sediment are removed.

\section{Materials and methods}

Study site

The study was carried out within the Municipal Marine Park of Recife de Fora in Porto Seguro, southeastern Brazil. The park is centered on an island $6 \mathrm{~km}$ from the coast of the first conservation unit in this area, established in 1997 , located at $16^{\circ} 23^{\prime} \mathrm{S}$ and $16^{\circ} 26^{\prime} \mathrm{S}$ and $39^{\circ} 00^{\prime} \mathrm{W}$ and $38^{\circ} 58^{\prime} \mathrm{W}$ (Fig. 1), and covers a total area of approximately $17.5 \mathrm{~km}^{2}$. The depth of the surrounding reef ranges from 6 to $8 \mathrm{~m}$ nearshore and may reach up to $15 \mathrm{~m}$ in the northeast offshore area (Costa et al. 2002; Prates 2006).

The study site selected for establishing the succession experiments, named Ponto Oeste $\left(16^{\circ} 24^{\prime} 36^{\prime \prime} \mathrm{S}\right.$; $38^{\circ} 59^{\prime} 08^{\prime \prime} \mathrm{W}$ ), is a sheltered nearshore reef (Fig. 1b). Visually, the reef flat was dominated by massive brain corals of Siderastrea stellate (Verril 1868) and Mussismilia braziliensis (Verril 1867) and branching corals of Mussismilia hartii (Verril 1868) and Millepora alcicornis (Linnaeus 1758), with CCAs growing among and over the corals. The reef flat is cut with grooves and is constantly submerged, with depths ranging from 0.5 to $3 \mathrm{~m}$ on the reef flat and $8 \mathrm{~m}$ near the soft bottom.

\section{Transects}

The linear point intercept method (LPI) was deployed along three $10 \mathrm{~m}$ transect lines, which were laid $1 \mathrm{~m}$ from each other and oriented parallel to the reef border. 


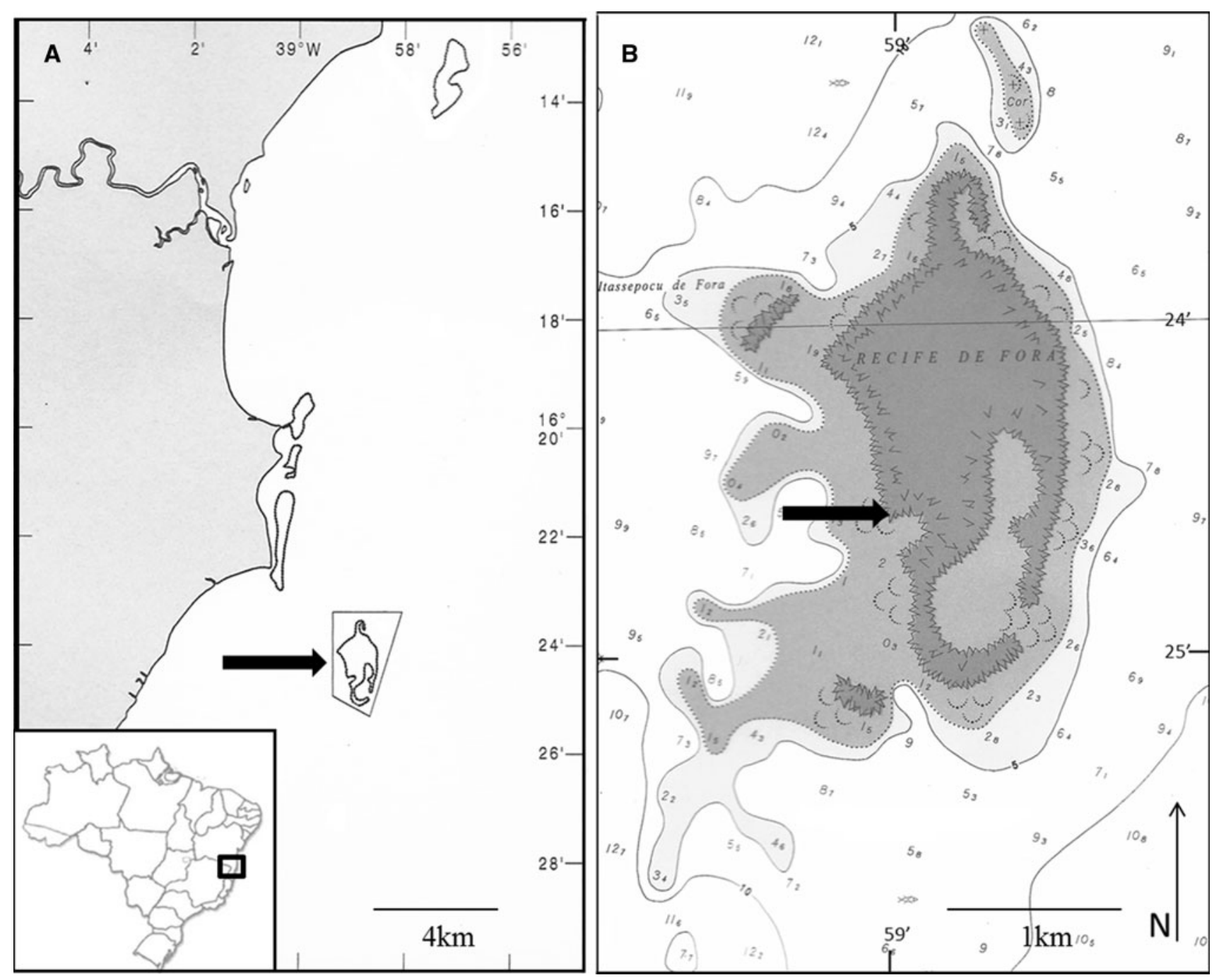

Fig. 1 Location of the Marine Park of Recife de Fora, state of Bahia, Brazil. a Coastline of southern Bahia; arrow indicates the position of the Marine Park; b Marine Park; arrow indicates the survey location

The number of times an organism found under 10 random sampling points on each transect line was counted and its overall proportion was calculated (method used to quantify CCA by Figueiredo and Steneck 2002; Villas Boas et al. 2005; Tâmega and Figueiredo 2007). Nandon and Stirling (2006) indicated that LPI was the most cost-effective means of measuring coral cover and at least as precise and accurate as the belt transect and the line transect methods. Because CCA were partially hidden by canopy algae and branching corals, they were removed or displaced prior to record. CCA were collected by using hammer and chisel at each random point, scuba or snorkel diving on the reef flat, and their species were identified.

\section{Succession}

Changes in colonization and competition over different periods of the year were assessed on 60 discs $(8 \mathrm{~cm}$ in diameter and $6 \mathrm{~mm}$ thick, handmade plastic), which were placed in the same area as the transect lines (Fig. 2). They were randomly distributed on horizontal surfaces of dead coralline sunlit areas of the reef flat close to the edge, and fixed in place by means of underwater epoxy putty (Tubolit MEN) (Figueiredo 1997). We used artificial discs because they offer the advantages of being replicable, independent, controllable and biota free (West and Crump 1974; Fletcher et al. 1985). The experiment started in February 2007, and ten discs were randomly removed at each time interval, after 13, 27, 75, 112, 237 and 333 days $(N=10)$. These time intervals were similar to those used in a previous study of CCA succession on a Caribbean reef (Adey and Vassar 1975). In the early stages of succession (13 and 27 days), all CCA recruits were counted on each disc under the stereoscope. For the other stages $(75,112,237$ and 333 days), we estimated the percentage cover of organisms by sampling 20 random points on each colonized disc using 


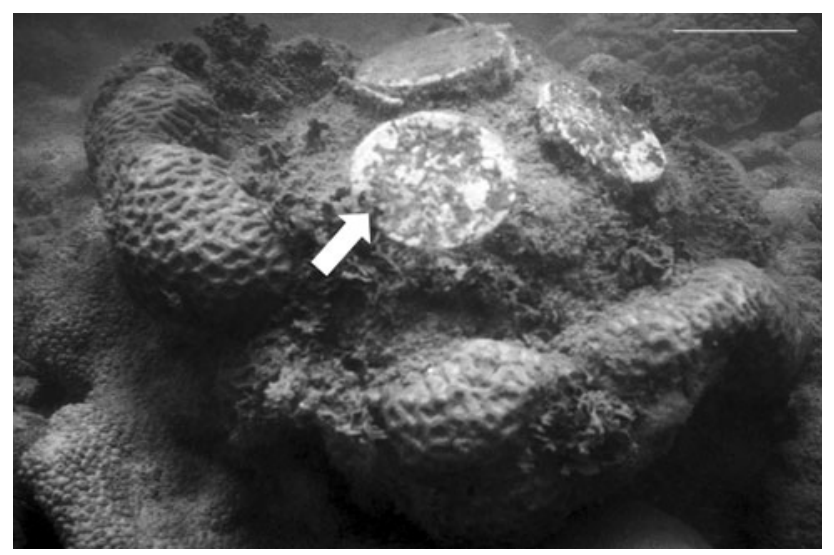

Fig. 2 Colonization discs fixed on the reef flat of the Marine Municipal Park of Recife de Fora (scale $8 \mathrm{~cm}$ ). (Photo: Juliano A. Oliveira)

random points under the stereoscope. Fish grazing marks (\% bites) were estimated at the same 20 random points (method of Figueiredo 1997).

\section{Disturbance}

In order to investigate the potential influence of physical disturbance on the cover of CCA and erect macroalgae and overgrowing margins of CCA, we placed 40 other discs at the same site as the succession study. To simulate a natural disturbance, half of the discs were brushed with plastic brushes at weekly intervals, and the other half were maintained undisturbed as controls $(N=20)$. After 75 and 237 days, discs from each treatment were randomly removed from the reef to quantify the presence and abundance of encrusting organisms $(N=10)$. Brushing is assumed to simulate general physical disturbance (Kendrick 1991), not specifically sedimentation but rather grazing, which is likely to remove macroalgae. The brushing treatments were manipulated and standardized in order to remove erect algae and their associated sediments, to further determine their effects on the CCA, since this might be important for succession.

Procedures in the laboratory: the discs collected were placed in running fresh water to remove sediment and salt, which might affect the quantification of organisms. Macroalgae were grouped according to the morpho-functional classification (Steneck and Dethier 1994), although based only on morphological and anatomical features. The CCA were identified by light and scanning electron microscopy. For taxonomic determinations, the vegetative and reproductive structures (color, external morphology, texture and margin growth) were evaluated. The cell structures (secondary pit connections; thallus organization; epithelial and subepithelial cells; shape, size and type of sporangial conceptacles and sores) were also analyzed. For analyses, the whole disc was investigated for the presence and abundance of each encrusting organism. Before CCA quantification organisms growing as top layer concealing the CCA were removed. The evaluation of margin overgrowth followed the method of Keats and Maneveldt (1994), where the "winning" alga was considered to be the one that covered the other.

Statistical analysis

A factorial experimental design was used to test the influence of physical disturbance on CCA. Percent cover data were arcsine-transformed before the evaluation of normal distribution and homogeneity of variances with Cochran's test (Underwood 1997). Differences in succession times were investigated using one-way analysis of variance (ANOVA). A posteriori Tukey test was used to compare more than two means of succession time intervals. The effects of physical disturbance by brushing and time on total abundance of CCA and erect macroalgae were tested using a two-way ANOVA, considering the factorial experimental design.

\section{Results}

Three species of CCA were identified. Pneophyllum conicum (Dawson) Keats, Chamberlain and Baba is an incrusting growth form with a thin pinkish thallus $(<200 \mu \mathrm{m})$ and an adhering margin; the tetrasporophyte conceptacle is markedly raised and unipored (Fig. 3a, b). Porolithon pachydermum (Foslie) Foslie is also an incrusting growth form, pinkish with an adhering margin, but with a thick thallus $(>200 \mu \mathrm{m})$; the tetrasporophyte conceptacle is flushed, unipored and slightly raised or sunken in relation to the thallus surface (Fig. 3c, d). Peyssonnelia sp. (Decaisne 1841 ) is an incrusting growth form, purple with a thick thallus ( $>200 \mu \mathrm{m})$, rough surface and adhering margin; with isolated sporangial sori among epithelial cells and unicellular rhizoids issuing from hypothallium cells (Fig. 3e, f).

\section{Transects}

On the reef flat, Pneophyllum conicum had the greatest coverage, twice that of Porolithon pachydermum. Foliose algae were mixed with sediments, therefore, scarcely noticed during the reef survey. Corals comprised $37 \%$ of the total cover (Fig. 4).

\section{General succession}

The coverage of morpho-functional groups on the colonization discs was estimated at four succession periods. Filamentous algae were abundant after 75 days (Fig. 5a), 
Fig. 3 a Porolithon

pachydermum incrusting growth form, b Tetrasporophyte conceptacle, c Peyssonnelia sp. incrusting growth form, d Unicellular rhizoids issuing from hypothallium cells, e Pneophyllum conicum incrusting growth form, f Tetrasporophyte conceptacle, g Overgrowth of Peyssonnelia sp. (a) on Porolithon pachydermum $(b)$ in histological section
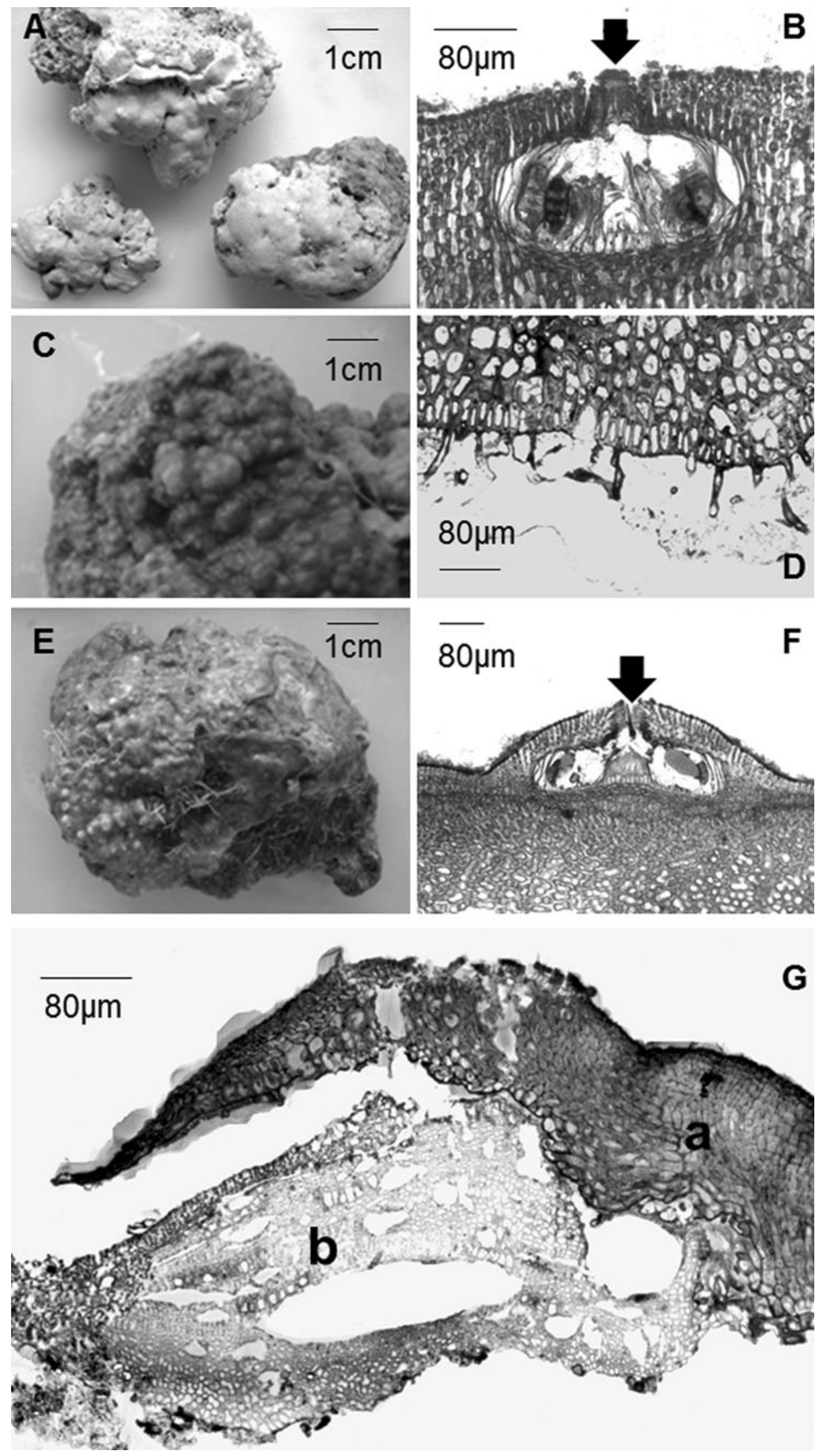


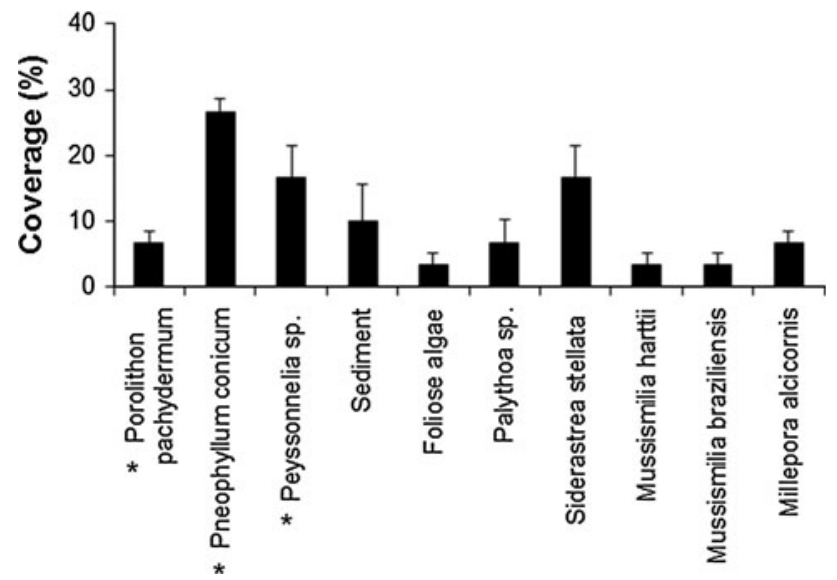

Fig. 4 Coverage of crustose coralline algae (indicated by the asterisks), natural uncovered sediment (Sediment), and foliose algae and incrusting fauna (last five bars) on reefs of the Marine Park of Recife de Fora. Mean and error bars $(N=30)$

rapidly occupying the available space remaining a dominant group through time CCA increased in abundance over time (ANOVA, $p=0.004$ ), and became close to coverage of filamentous algae (Fig. 5b). This abundance pattern was maintained for 237 days, when coral recruits were observed for the first time (Fig. 5c). After 333 days, CCA tended to be the most abundant organisms, followed by filamentous and corticated algae and coral recruits (Fig. 5d). Corticated and foliose algae were less common on discs. Grazing marks were visible from 237 days onwards $(0.5-1 \%)$.

\section{CCA succession}

Succession was analyzed at six different times. For the CCA, after 13 days, a mean of 43 crusts per disc was found, with a small number identified as Pneophyllum conicum. Identification at this stage was difficult because most crusts had no reproductive structure. After 27 days, a mean of 46 crusts had settled, and P. conicum was also identified. After 75 days, $P$. conicum was the main colonizer among CCA. Crusts of different individuals of this species were observed fusing their margins on the colonization discs, increasing their coverage after 112 days. $P$. conicum continued to be the dominant crust up to 333 days (Fig. 6) (ANOVA $F=7.15, p<0.001)$. After 112 days, two other species were found (Fig. 6), Porolithon pachydermum and Peyssonnelia sp., both with similar abundances but with no fusion margins between crusts of the same species. After 237 days of colonization, $P$. pachydermum and Peyssonnelia sp. continued to be present on the discs, but their coverage increased only after 333 days (ANOVAs, respectively, $F=6.68, p=0.001$ and $F=5.44, p=0.003)$. The abundance pattern on the discs was similar to that on the reef flat, but Peyssonnelia sp. was relatively more abundant on

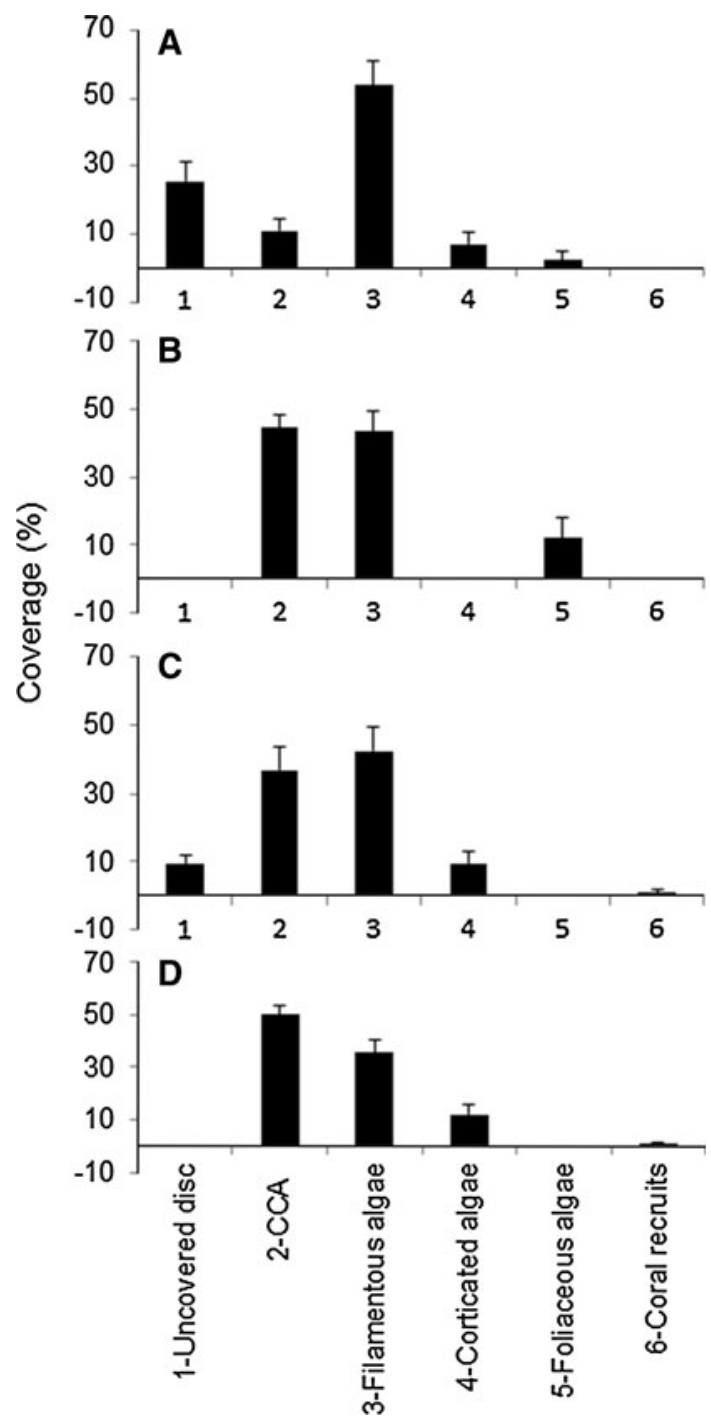

Fig. 5 Percentage coverage of macroalgal morphological groups and recruited corals on colonization unbrushed discs at a 75 days, b 112 days, c 237 days and d 333 days. Mean and error bars $(N=10$ per time $)$

the reef than on the discs. Coral cover was lower on the discs than on the reefs, probably because the experiment did not run long enough to allow full development of the coral.

Overall, Pneophyllum conicum tended to be the most abundant species in all treatments. However, $P$. conicum was competitively inferior in $100 \%$ of margin encounters, either with Porolithon pachydermum or Peyssonnelia sp., both of which have a thicker thallus. Peyssonnelia sp. was competitively superior to $P$. pachydermum in $75 \%$ of crust margin encounters (Fig. 3g).

Physical disturbance

Total coverage of CCA increased significantly between 75 and 237 days in both treatments (Fig. 7a, b). A significant 


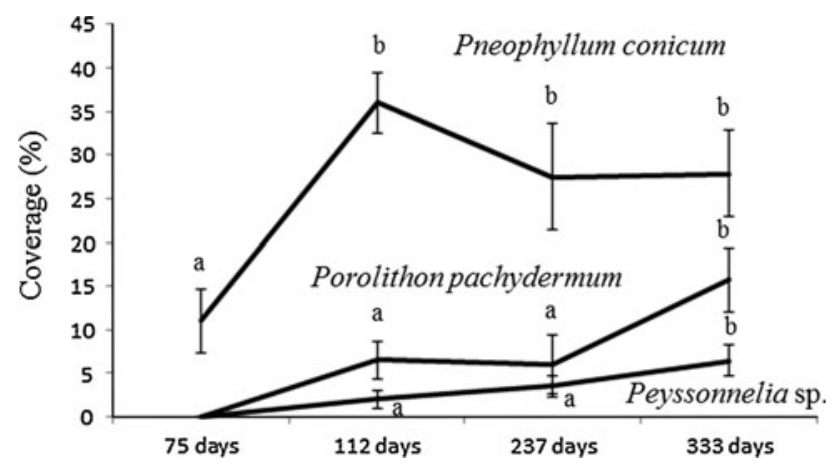

Fig. 6 Percentage coverage of three species of incrusting coralline algae surveyed on colonization discs at four succession dates. Letters above the columns indicate significant differences among means (ANOVA, Tukey post hoc test, $P=0.05$ ). Mean and error bars $(N=10$ per time $)$

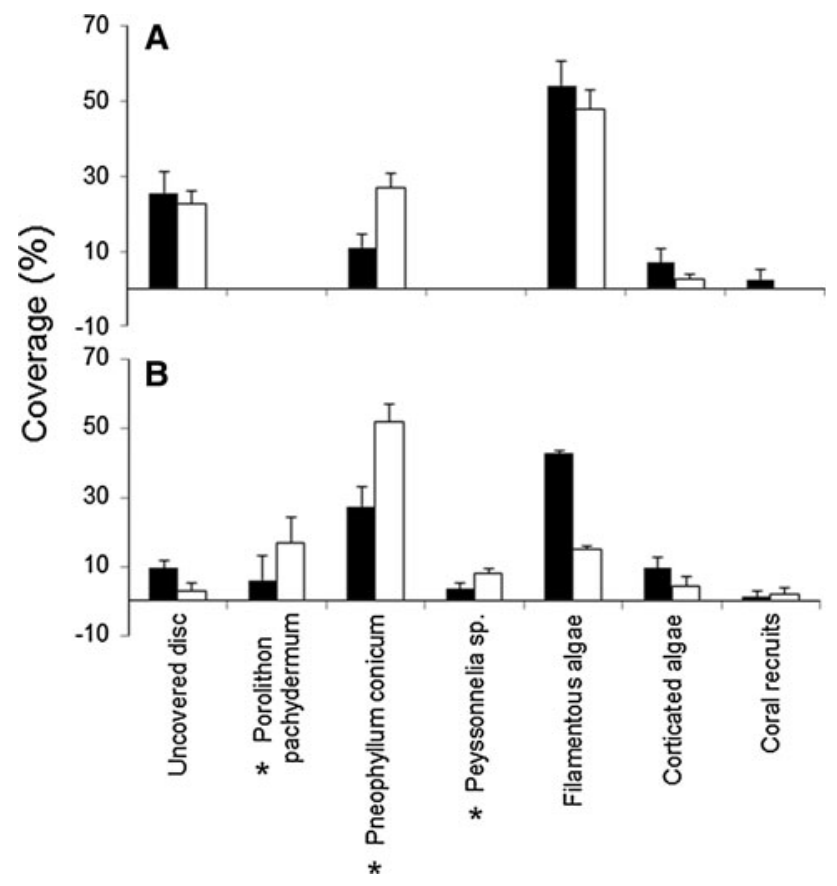

Fig. 7 Effect of disturbance by brushing of experimental discs on groups of algae and incrusting fauna on discs after a 75 days and b 237 days of colonization. Mean and error bars $(N=10$ per treatment and time). Black bars control discs, white bars: brushed discs. CCAs are indicated by asterisks

interaction between time and cover was obtained for erect algae (Fig. 7b) (Table 2a), in which the disturbance effect was detected only after 237 days, when erect algae decreased in abundance in the brushed treatment (ANOVA, $F=10 ; p=0.004)$. This decrease was only due to filamentous algae (ANOVA, $F=8.36 ; p=0.009$ ) and not to corticated algae (ANOVA, $F=1.31 ; p=0.266$ ). Filamentous algae comprised at least $40 \%$ of the cover, dominating the other groups of macroalgae in both the different times and brushing treatments. Grazing marks covered only $0.5 \%$ of the disc surfaces after 237 days.
Table 2 Analysis of variance of physical disturbance effects on (A) erect fleshy algae and (B) coralline algae Pneophyllum conicum

\begin{tabular}{llllc}
\hline Source & DF & MS & F & $p$ value \\
\hline A-erect algae & & & & \\
Time & 1 & 0.65 & 13 & $<0.001$ \\
Disturbance & 1 & 0.08 & 1.8 & 0.18 \\
Time $\times$ Disturbance & 1 & 0.58 & 11 & 0.001 \\
Error & & 0.04 & & \\
B-Pneophyllum conicum & & & \\
Time & 1 & $2.07 \times 10^{-18}$ & 100 & $<0.001$ \\
Disturbance & 1 & $1.86 \times 10^{-17}$ & 9 & 0.005 \\
Time $\times$ Disturbance & 1 & $2.11 \times 10^{-16}$ & 1 & 0.31 \\
Error & & $2.06 \times 10^{16}$ & & \\
\hline
\end{tabular}

The effect of physical disturbance on the cover of CCA species was significant and independent of the colonization period, with greater incrustation of Pneophyllum conicum on the brushed discs (Table 2b). The coverage of Porolithon pachydermum and Peyssonnelia sp. was not affected by brushing after 237 days (ANOVA, $F=3.45 ; p=0.07$ and $F=3.33 ; p=0.57$, respectively), and did not occur on the discs before 75 days.

\section{Discussion}

This coral-reef community is characterized by an extensive cover of thin crusts of Pneophyllum conicum, rather than the thicker crusts of Porolithon pachydermum and Peyssonnelia $\mathrm{sp}$. The introduction of a bare substratum, in this case discs for colonization, quickly resulted in recruitment of CCA together with macroalgae, mainly filamentous algae. Indeed, coralline crusts are known to rapidly recruit on bare substratum within a short period at the beginning of succession (Paine 1984; Steneck 1986; Dethier et al. 1991; Kendrick 1991), with thin crusts bearing reproductive features in less than 100 days (Steneck 1986).

Overall, a two-stage succession pattern is described in the Caribbean: (1) thin-crusted algae grow more rapidly than their thicker competitors in early succession; (2) thick crusts are observed after 100 days of colonization, and remain dominant in mature reef communities (Adey and Vassar 1975; Littler and Littler 1984; Steneck 1986). In our study, CCA rapidly colonized the substratum, and these pioneer crusts fused their thalli, dominating the available substratum. Reproductive structures of thin-crusted Pneophyllum conicum were found after 14 days, and this species continued to dominate throughout the study period. Thick crusts of Porolithon pachydermum and Peyssonnelia sp. recruited after 112 days. 
Porolithon pachydermum and Peyssonnelia sp. were competitively superior to Pneophyllum conicum in thallusmargin encounters on discs. In the analysis of competitive interactions, morphological features of the algal thallus such as thickness and adherent margins might have influenced the result of competition for space. These results agree with the expected competition patterns in which thick incrusting organisms generally cover the thinner ones, which are at a competitive disadvantage where margins meet (Steneck 1986; Dethier et al. 1991; Steneck et al. 1991; Keats and Maneveldt 1994). This pattern may be inverted in environments that are subject to high grazing pressure, where the rapid marginal growth of thin crusts allows them to overgrow thicker crusts (Paine 1984), and a thin crust might become a thick layer by overgrowing its own damaged thallus (Steneck et al. 1991). A change in pattern might also occur in a thin thallus with an imbricate surface resulting from regeneration of the thallus surface margin, which upon coming into contact, decreases or ceases coverage through a thick thallus (Keats and Maneveldt 1994). Herbivore pressure was considered to be low at the site studied here because grazing marks were rarely found on the discs. Therefore, grazing pressure cannot explain the dominance of thinner crusts, as opposed to the competitive patterns expected at the encounter of margins.

A second factor that may explain the pattern of thin crusts being more abundant than thick crust is the high accumulation of sediments $\left(10 \mathrm{mg} \mathrm{cm}^{-2}\right.$ day $\left.^{-1}\right)$ expected on near shore reefs in the region (Dutra et al. 2004). Both decrease incident irradiance and thereby may have limited the thick crusts of Porolithon pachydermum, favoring the establishment of the thin crusts of Pneophyllum conicum. CCA on reefs have been reported to be sensitive to sediment deposition (Kendrick 1991). The low irradiance may also reduce the productivity of thick crusts on reefs, as previously shown for Porolithon onkodes (Heydrich) Foslie (Littler 1973); and also decrease their growth rate. Previous studies have described a reduction in the abundance of thick CCA on reefs as the depth increases, and this pattern was explained by low-light levels (Figueiredo 1997; Steneck 1997). CCA may also decrease in thickness with an increase in depth and lower-light levels (Dethier et al. 1991; Figueiredo and Steneck 2002). It may be argued that thick CCA reduce competitiveness compared to the thin thalli of $P$. conicum in shallow water but inverse in deeper areas (Figueiredo et al. 2012).

A third explanation for the observed dominance (in transects and succession plates) of Pneophyllum conicum: they may occupy available colonization space more quickly than species with a thicker thallus, which have growth rates lower than other crusts (Adey and Vassar 1975; Steneck 1986; Figueiredo et al. 2000). CCA grow laterally at their margins, but also vertically, increasing their thickness by adding a layer of meristematic cells (Steneck 1986). Consequently, thick crusts that invest in vertical growth were suggested to be less productive and competitive than thin crusts, since they produce more no photosynthesizing cells below the pigmented upper layer (Steneck and Adey 1976). This may explain why P. conicum is able to dominate an assemblage, even if it is less competitive upon encountering the margins of Porolithon pachydermum and Peyssonnelia sp.

During the disturbance experiments primary space became available more frequently than without disturbance. This led to an increase in CCA and concomitant decrease in erect fleshy algae. Even here thin $P$. conicum remained dominant over thicker crusts. Of the colonizing crustose species, $P$. conicum remained dominant over thicker crusts because of high tetraspore production. This pattern might be explained because fouling algae affect the growth rates of coralline crusts beneath mainly thick-thallus species by reducing light to a critical level (Figueiredo et al. 2000).

CCA require a certain amount of disturbance to reduce competition with other algae and invertebrates, whether by physical or biological mechanisms (Littler and Doty 1975; Steneck 1997, 1986, 1988, 1990; Kendrick 1991; Steneck and Dethier 1994). Physical disturbances require wave energy, currents or grazing, and are normally associated with an increase in the productivity of tropical filamentous algae and CCA (Adey and Goertemiller 1987; Steneck 1997). However, abrasion has been reported as necessary to decrease the competition between CCA and filamentous algae (Steneck 1997). Kendrick (1991) demonstrated a rapid increase in coverage of CCA subjected to physical disturbance through abrasion, whereas filamentous algae proliferated in environments subject to sediment deposition or water turbulence, even without abrasion effect.

The interactions recorded here revealed the existence of a tolerance of CCA species throughout the succession process against physical disturbance caused by brushing the colonizing assemblage. Connell and Slatyer (1977) reported that with limited light, the model of tolerance predicts that the set of more tolerant species (e.g., those capable of growing under low resource levels) will eventually dominate in a balanced community. This successional pattern leads to a community comprised of the most efficient species in exploiting resources, each one presumably specializing in different types or proportions of resources (Connell 1975, 1976). In contrast to the findings of Adey and Vassar (1975) who described an inhibition model (sensu Connell and Slatyer 1977) for succession of CCAs with a gradual change to a dominance of long lived species, the succession pattern observed here was reverse and unusual. As experimental duration only comprised approx. 1 year, it should be followed in future whether 
succession pattern of CCA stabilize already after 1 year or need longer time periods.

Acknowledgments We thank the staff of the Municipal Marine Park for their support in our field work, in particular Dr. Renata Arantes and Leones Lopes for brushing the discs regularly. Tubolit provided the epoxy putty used in the experiments. Petrobras Ambiental and the Coral Vivo Project awarded an MSc scholarship to the first author. Our special thanks to Dr. Vera Huszar and two reviewers for their helpful advice during the final version of this manuscript. We are also grateful to Proof Reading services of UK and to Dr. Janet. W. Reid (JWR Associates, USA) for improving the English version.

\section{References}

Adey WH (1998) Coral reefs: algal structured and mediated ecosystems in shallow, turbulent, alkaline waters. J Phycol 34:393-406

Adey WH, Goertemiller T (1987) Coral reef algal turf: master producers in nutrient poor seas. Phycologia 26:74-386

Adey WH, Vassar JM (1975) Colonization, succession and growth rates of tropical crustose coralline alga (Rhodophyta, Cryptonemiales). Phycologia 14:55-69

Connell JH (1975) Some mechanisms producing structure in natural communities: a model and evidence from field experiments. In: Cody ML, Diamond JM (eds) Ecology and evolution of communities. Harvard University Press, Cambridge, pp 460-490

Connell JH (1976) Competitive interactions and the species diversity of corals. In: Mackie GO (ed) Coelenterate ecology and behavior. Plenum Press, New York, pp 51-58

Connell JH, Slatyer RO (1977) Mechanisms of succession in natural communities end their role in community stability and organization. Am Nat 111:1119-1144

Costa OS Jr, Attrill MJ, Pedrini AG, De-Paula JC (2002) Benthic macroalgal distribution in coastal and offshore reefs at Porto Seguro Bay, Brazilian Discovery Coast. In: Proceedings of the 9th International Coral Reef Symposium, pp 507

Dethier MN, Paul KM, Woodbury MM (1991) Distribution and thickness patterns in subtidal encrusting algae from Washington. Bot Mar 34:201-210

Dutra LXC, Kikuchi RKP, Leão Z (2004) Effect of sediment accumulation on reef corals from Abrolhos, Bahia, Brazil. J Coast Res SI (Proceedings of the 8th International Coastal Symposium) 39:633-638. (ISSN 0749-020)

Figueiredo MAO (1997) Colonization and growth of crustose coralline algae in Abrolhos, Brazil. In: Proceedings of the 8th International Coral Reef Symposium, pp 694

Figueiredo MAO (2006) Diversity of macrophytes on the Abrolhos Bank, Brazil. In: Dutra GF, Allen GR, Werner T, McKenna S (eds) Rapid marine biodiversity assessment of the Abrolhos Bank, Bahia, Brazil. RAP Bull of Biol Assess 38:67-74

Figueiredo MAO, Steneck RS (2002) Floristic and ecological studies of crustose coralline algae on Brazil's Abrolhos reefs. 9th International Coral Reef Symposium Bali, pp 498

Figueiredo MAO, Kain JM, Norton TA (2000) Responses of crustose corallines to epiphyte and canopy cover. J Phycol 36:17-24

Figueiredo MAO, Horta PA, Pedrini AG, Nunes JMC (2008) Benthic marine algae of the coral reefs of Brazil: a literature review. Oecol Bras 12:258-269

Figueiredo MAO, Coutinho R, Villas-Boas AB, Tâmega FTS, Mariath R (2012) Deep-water rhodolith productivity and growth in the southwestern Atlantic. J Appl Phycol 24:487-493
Fletcher RL, Baier RE, Fornalik MS (1985) The effects of surface energy on germling development of some marine macroalgae. $\mathrm{Br}$ Phycol J 20:184-185

Gherardi DFM, Bosence DWJ (2001) Composition and community structure of the coralline algae reef from Atol das Rocas, South Atlantic, Brazil. Coral Reefs 19:205-219

Keats DW, Maneveldt G (1994) Leptophytum foveatum Chamberlain and Keats (Rhodophyta, Corallinales) retaliates against competitive overgrowth by other encrusting algae. J Exp Mar Ecol 175:243-251

Keats DW, Mathews I, Maneveldt G (1994) Competitive relationships and coexistence in a guild of crustose algae in the eulittoral zone, Cape Province, South Africa. S Afr J Bot 60:108-113

Kendrick GA (1991) Recruitment of coralline crusts and filamentous turf algae in the Galapagos archipelago: effect of simulated scour, erosion and accretion. J Exp Mar Ecol 147:47-63

Leão ZMAN (1996) The coral reefs of Bahia: morphology, distribution and the major environmental impacts. An Acad Bras Ciênc 68:439-452

Leão Z, Dominguez JML (2000) Tropical coast of Brazil. Mar Pollut Bull 41:112-122

Leão Z, Kikuchi RKP (2005) A relic coral fauna threatened by global changes and human activities, Eastern Brazil. Mar Pollut Bull 51:599-611

Littler MM (1973) The population and community structure of Hawaiian fringing-reef crustose Corallinaceae (Rhodophyta, Cryptonemiales). J Exp Mar Ecol 11:103-120

Littler MM, Doty MS (1975) Ecological components structuring the seaward edges of tropical Pacific reefs: the distribution, communities and productivity of Porolithon. J Ecol 63:117-129

Littler MM, Littler DS (1984) Relationships between macroalgal functional form groups and substrata stability in a subtropical rock intertidal system. J Exp Mar Biol Ecol 74:13-34

Nandon MO, Stirling G (2006) Field and simulation analyses of visual methods for sampling coral cover. Coral Reefs 25: $177-185$

Paine RT (1984) Ecological determinism in the competition for space. Ecol 65:1339

Prates APL (2006) Atlas dos Recifes de Coral nas Unidades de Conservação Brasileiras. Brasília, MMA, SBF, pp 232

Quinn F (1982) Competitive hierarchies in marine benthic communities. Oecol (Berlin) 54:129-135

Ringeltaube P, Harvey A (2005) Non-geniculate coralline algae (Corallinales, Rhodophyta) on Heron Reef Great Barrier Reef (Australia). Bot Mar 43(5):431-454

Steneck RS (1986) The ecology of coralline algal crusts: convergent patterns and adaptive strategies. Ann Rev Ecol Syst 17:273-303

Steneck RS (1988) Herbivory on coral reefs: a synthesis. Proceedings of the 6th International Coral Reefs Symposium, Australia, pp 49

Steneck RS (1990) Herbivory and the evolution of nongeniculate coralline algae (Rhodophyta, Corallinales) in the North Atlantic and North Pacific. In: Garbary DJ, South GR (eds), Evolutionary Biogeography of the North Atlantic. NATO ASI Series, G, Ecological Sciences 22: 107-129

Steneck RS (1997) Crustose corallines, other algal functional groups, herbivores and sediments: complex interactions along reef productivity gradients. Proceedings of the 8th International Coral Reefs Symposium, pp 700

Steneck RS, Adey WH (1976) The role environment in control of morphology in Lithophyllum congestum, a Caribbean algal ridge builder. Bot Mar 19:197-215

Steneck RS, Dethier MN (1994) A functional group approach to the structure of algal dominated communities. Oikos 69:476-498

Steneck RS, Hacker SD, Dethier MN (1991) Mechanisms of competitive dominance between crustose coralline algae: an herbivore-mediated competitive reversal. Ecology 72:938-950 
Tâmega FTS, Figueiredo MAO (2007) Distribution of crustose coralline algae (Corallinales, Rhodophyta) in the Abrolhos reefs, Bahia, Brazil. Rodriguésia 58:941-947

Underwood AJ (1997) Experiments in ecology. Their logical design and interpretation using analysis of variance. Cambridge University Press, Cambridge, p 504

Villaça R, Pitombo FB (1997) Benthic communities of shallow-water reefs of Abrolhos, Brazil. Rev Bras Oceanogr 45:35-43
Villas Boas AB, Figueiredo MAO, Villaça RC (2005) Colonization and growth of crustose coralline algae (Corallinales, Rhodophyta) on the Rocas Atoll. Braz J Oceanogr 53:147-156

West JA, Crump E (1974) The influence of substrate and spore concentration on spore survival and germination in Gigartina and Petrocelis (Rhodophyta). J Phycol 10(Suppl):12 